the world. It is an excellent forum for anyone interested in methods, problems and potentials of on-farm research. Contact Dr. Tom Westing, Associate Dean, International Agricultural Programs, University of Arkansas, College of Agriculture and Home Economics, 300 Hotz Hall, Fayetteville, Arkansas 72701.

Peter E. Hildebrand, Professor

Food and Resource Economics Department

Institute of Food and Agricultural Sciences

University of Florida

Gainesville, FL 32611

\section{Cultural pest control}

We are doing a study to make available the best information on cultural controls of field and horticultural insect pests, for farmers and horticulturists who want to reduce their dependence on pesticides. This will be based on practical experience of farmers and published information.

If you have successfully used cultural methods for control of any insect pests (planting design, rotation, management practices such as cultivation, fertilization or management of adjacent environments, etc.), please write to us as soon as possible giving all the details. Our final report will be completed by Fall 1988, and the results will be published soon after.

This is your opportunity to be part of the solution.

Please send information to: Renee Lapointe/Micheline Levesque, Ecological Agriculture Projects, Box 191, Macdonald College, 21,111 Lakeshore, Ste. Anne de Bellevue, QC, Canada H9X 1CO, telephone (514) 398-7771.

Stuart B. Hill, Ph.D.

Associate Professor, Entomology

Macdonald College

21,111 Lakeshore Road

Ste. Anne de Bellevue

$P Q$ Canada H9X $1 C O$

\section{On-farm research}

We were pleased to see the article about on-farm research in the last issue of AJAA. We, too, feel that this type of research can play an important part in the wider acceptance by farmers of sustainable ag practices, both as demonstrational plots and by gaining new knowledge of regenerative systems. There are a few additional points we would like to add to this discussion based on our experience working in this area.

Dr. Lockeretz, in his treatment of on-farm research, limits his discussion to why researchers should consider conducting such investigations. Although we welcome their involvement, we feel that probably the greatest potential for on-farm research making an impact in agriculture is for farmers to get involved in developing and testing their own ideas. Many farmers have excellent ideas of innovative crop and livestock production practices which, if given the ability to conduct a valid test, could contribute greatly to agricultural science.

This is the philosophy of the on-farm research projects the organizations we represent have developed in the last few years. Cooperating farmers in both the Rodale Institute and Practical Farmers of Iowa programs are free to choose their research agendas (with technical help from paid staff) based on their experience, soil type, climate, ag enterprise, equipment available, etc. Out of these efforts we hope will come new ideas in using cover crops, safe weed control, and lower input costs.

We are trying to make the whole effort of doing good research accessible to farmers. Cooperators in our programs take soil and tissue samples and collect such data as percent groundcover, weed infestations, earthworm counts, etc., depending on the trial. We are also in the process of testing a yield monitor which is attached to the combine for easily recording grain yields. The experimental design used is simple, yet statistically valid. It calls for few treatments (preferably two) laid out across the length of the field in side by side strips, the width of which is determined by the equipment on hand.

The treatments are replicated at least 6 times and randomized within each replicate. Yield determinations are made by conventionally harvesting the entire plot. This system allows for doing an analysis of variance to determine significance. A surprising number of farmers are willing to learn to do the statistics or have software programs to run the numbers. All of these efforts are for the purpose of making on-farm research a powerful tool in the hands of those progressive farmers who consider new ideas and are willing to test them.

One of Dr. Lockeretz's contentions is that basic research should also be carried out on-farm. We think that this is a contradiction in terms and cannot think of an example (except for items 1-3 listed in his paper which are specific to soil type or large plots which may not be available on a research station) where it would be to a researcher's advantage to do this type of work on-farm. On-farm research by definition is highly applied. The effectiveness of treatments is based on factors such as labor and equipment considerations, economic feasibility, fitting into practical rotations, etc. Basic ag research is concerned not with these items, but rather how things work biologically or chemically.

Lastly, in our efforts to aid farmers in conducting their own research, we are in the process of putting an instructional guide together. Our hope is that extensionists, researchers, and vo-ag teachers, as well as farmers, can use the guide in conducting practical and statistically valid research on the farm. Copies will be available from the Rodale Institute by Fall of 1988 .

\section{Ken McNamara}

Midwest On-Farm Research Coordinator

Rodale Institute

Emmaus, PA 18049

Dick Thompson

Practical Farmers of Iowa

Rt. 2, Box 132

Boone, IA 50036

Letters on topics likely to be of interest to AJAA readers are welcome. Since our space is limited, we reserve the right not to publish all letters or, at times, to publish only excerpts from them. To take part in this exchange of ideas and news, write to the Editor. 